\title{
A Last Glacial Maximum forcing dataset for ocean modelling
}

\author{
Anne L. Morée ${ }^{1}$ and Jörg Schwinger ${ }^{2}$ \\ ${ }^{1}$ Geophysical Institute, University of Bergen and Bjerknes Centre for Climate Research, 5007 Bergen, Norway \\ ${ }^{2}$ NORCE Climate, Bjerknes Centre for Climate Research, 5007 Bergen, Norway \\ Correspondence: Anne L. Morée (anne.moree@uib.no)
}

Received: 16 May 2019 - Discussion started: 1 July 2019

Revised: 30 September 2020 - Accepted: 10 October 2020 - Published: 20 November 2020

\begin{abstract}
Model simulations of the Last Glacial Maximum (LGM; 21000 years before present) can aid the interpretation of proxy records, can help to gain an improved mechanistic understanding of the LGM climate system, and are valuable for the evaluation of model performance in a different climate state. Ocean-ice only model configurations forced by prescribed atmospheric data (referred to as "forced ocean models") drastically reduce the computational cost of palaeoclimate modelling compared to fully coupled model frameworks. While feedbacks between the atmosphere and ocean and sea-ice compartments of the Earth system are not present in such model configurations, many scientific questions can be addressed with models of this type. Our dataset supports simulations of the LGM in a forced ocean model set-up while still taking advantage of the complexity of fully coupled model set-ups. The data presented here are derived from fully coupled palaeoclimate simulations of the Palaeoclimate Modelling Intercomparison Project phase 3 (PMIP3). The data are publicly accessible at the National Infrastructure for Research Data (NIRD) Research Data Archive at https://doi.org/10.11582/2020.00052 (Morée and Schwinger, 2020). They consist of 2-D anomaly forcing fields suitable for use in ocean models that employ a bulk forcing approach and are optimized for use with CORE forcing fields. The data include specific humidity, downwelling long-wave and short-wave radiation, precipitation, wind ( $v$ and $u$ components), temperature, and sea surface salinity (SSS). All fields are provided as climatological mean anomalies between LGM and pre-industrial (PI) simulations. These anomaly data can therefore be added to any pre-industrial ocean forcing dataset in order to obtain forcing fields representative of LGM conditions as simulated by PMIP3 models. Furthermore, the dataset can be easily updated to reflect results from upcoming and future palaeo-model intercomparison activities.
\end{abstract}

\section{Introduction}

The Last Glacial Maximum (LGM; $21 \mathrm{ka}$ ) is of interest to the climate research community because of the relative abundance of proxy data and because it is the most recent profoundly different climatic state of our planet. For these reasons, the LGM is extensively studied in modelling frameworks (e.g. Menviel et al., 2017; Brady et al., 2012; OttoBliesner et al., 2007; Bouttes et al., 2011; Buchanan et al., 2016; Lynch-Stieglitz et al., 2016; Kageyama et al., 2017). Model simulations of the past ocean can not only provide a method to gain a mechanistic understanding of marine proxy records, but they can also inform us about model performance in a different climatic state of the Earth system (Braconnot et al., 2012). Typical state-of-the-art tools to simulate the (past) Earth system are climate or Earth system models as used, for example, in the Coupled Model Intercomparison Project phase 5 (CMIP5; Taylor et al., 2011). Besides simulating our present climate, these CMIP5 models are also used to simulate past climate states (such as the LGM) in the Palaeoclimate Modelling Intercomparison Project phase 3 (PMIP3). However, the computational costs and runtime of such fully coupled model frameworks are a major obstacle for their application to palaeoclimate modelling. Palaeocli- 
mate modelling optimally requires long simulations (thousands to tens of thousands of years) in order to provide the necessary time for relevant processes to emerge (e.g. $\mathrm{CaCO}_{3}$ compensation) (Braconnot et al., 2007). Complex fully coupled models can not typically be run into full equilibrium (which requires hundreds to thousands of years of integration) due to computational costs (Eyring et al., 2016). Therefore, the PMIP3 models exhibit model drift (especially in the deep ocean; e.g. Marzocchi and Jansen, 2017). Since significant differences between a (drifting) non-equilibrated state and the equilibrium model state can impede the comparison of model results with proxy data, a well equilibrated model with minimal drift is desirable. The third phase of the PMIP project (Braconnot et al., 2012) limits global mean sea surface temperature drift to under $0.05 \mathrm{~K}$ per century and requires the Atlantic Meridional Overturning Circulation to be stable (Kageyama et al., 2018).

We refer to a "forced ocean model" as a model of the ocean-sea-ice-atmosphere system in which the atmosphere is represented by prescribed 2-D forcing fields. Such model set-ups have been extensively used in model intercomparison studies such as the Coordinated Ocean-ice Reference Experiments (COREs; Griffies et al., 2009) and more recently in the CMIP6 Ocean Model Intercomparison Project (OMIP; Griffies et al. 2016). A forced ocean model can be used whenever ocean-atmosphere feedbacks are of minor importance, and it has the advantage of reducing the computational costs - making longer or more numerous model runs feasible. The use of PMIP output in forced ocean modelling is common practice (e.g. Muglia and Schmittner, 2015; Khatiwala et al., 2019). Until now, however, there is no standardized dataset available that can be used to easily derive a Last Glacial Maximum model forcing. Therefore, we present 2-D (surface) anomaly fields of CMIP5/PMIP3 experiments of "lgm" (representing the Last Glacial Maximum state of the Earth system) minus "piControl" (representing the pre-industrial, PI, state) calculated from monthly climatological PMIP3 output. The PMIP3 output is the result of global boundary conditions and forcings (such as insolation and ice sheet cover) applied in the fully coupled PMIP3 models (Braconnot et al., 2012). Our dataset (Morée and Schwinger, 2020) is a unique compilation of existing data, which has been processed and reformatted such that it can be readily applied in a forced ocean model framework that uses a bulk forcing approach similar to Large and Yeager (2004). Since this approach has been popularized through coordinated model intercomparison activities (Griffies et al., 2009), a majority of forced ocean models today use this approach. The 2-D anomaly fields presented here can be added to the pre-industrial forcing of a forced ocean model in order to obtain an atmospheric forcing representative of the LGM. The data are climatological mean anomalies, and as such they are suitable for equilibrium LGM "time-slice" modelling of the ocean. In Sect. 2, a general description of the dataset and data sources is provided alongside an overview of the variables (Table 1). The descrip- tion of the procedure followed to make this dataset (Sect. 3) should support any extension of the dataset with additional (PMIP-derived) variables if needed. The PMIP4 guidelines (Kageyama et al., 2017) can support users in designing a specific model set-up, for example, regarding the land-sea mask, trace gas concentrations, river run-off, or other conditions and forcings that one would want to apply to a model. Limitations of the dataset are discussed in Sect. 4.

\section{General description of the dataset}

The data presented in this article are 2-D anomaly fields of the LGM versus the pre-industrial state based on PMIP3 (Braconnot et al., 2012). We note that the PMIP3/CMIP5 pre-industrial state, which is the result of piControl experiments, represents the year 1850 and is therefore strictly speaking already influenced by anthropogenic forcing (e.g. Eyring et al., 2016). Our anomaly fields can be used as atmospheric LGM forcing fields for ocean-only model setups when added to pre-industrial forcing fields (as done by, for example, Muglia and Schmittner, 2015; Khatiwala et al., 2019) and are optimized for use in combination with CORE forcing fields (Griffies et al., 2009). We note that the CORE forcing is based on modern era (1948-2009) reanalysis and observations and thus is not a pre-industrial forcing. However, the anthropogenic climate signal contained in these data is relatively small, particularly in comparison to the uncertainties of the LGM-PI anomalies (see below). The basis of the anomaly data is monthly climatological PMIP3 output. Any variables presented at sub-monthly time resolutions are therefore time-interpolated. We chose to timeinterpolate the variables to their respective time resolution in the CORE Normal Year Forcing format (CORE-NYF; Large and Yeager, 2004). The anomalies are calculated as the mean of the difference between monthly climatologies of the "lgm" and "piControl" PMIP3 model runs. In cases where modelling groups provided more than one ensemble member, we included only the first member in our calculations. The data are the mean anomaly of five PMIP3 models (CNRM-CM5, IPSL-CM5A-LR, GISS-E2-R, MIROCESM, and MRI-CGCM3; Table 2) as only these models provide output for all variables. A discussion on the limitations of our dataset is provided in Sect. 4.

The variables are (i) near-surface specific humidity, (ii) downwelling long-wave radiation, (iii) downwelling short-wave radiation, (iv) precipitation, (v) wind ( $v$ and $u$ components), (vi) near-surface temperature, and (vii) sea surface salinity (SSS) (Table 1). The SSS anomaly field can be used to adjust SSS restoring in LGM simulations.

All variables (Sects. 3.1-7) of the monthly climatological PMIP3 output have been regridded (Table 3, \#1), averaged (Table 3, \#2), and differenced (Table 3, \#3) to calculate the anomaly fields. Additional procedures for each variable are provided in the respective part of Sect. 3, together with 
Table 1. Summary of the data showing variable description, units, format (lat $\times$ long, time), and NetCDF variable name(s). Formats follow CORE conventions (Large and Yeager, 2004). The wind component variables are provided in separate files (Morée and Schwinger, 2020). In each NetCDF file (i.e. for each variable), the model spread is provided alongside the anomaly field named "variablename_spread".

\begin{tabular}{llll}
\hline Variable description & Units & Resolution (lat $\times$ long), time & Variable name \\
\hline Specific humidity & $\mathrm{kg} \mathrm{kg}^{-1}$ & $94 \times 192,1460$ & huss \\
Downwelling long-wave radiation & $\mathrm{W} \mathrm{m}^{-2}$ & $94 \times 192,365$ & rlds \\
Downwelling short-wave radiation & $\mathrm{W} \mathrm{m}^{-2}$ & $94 \times 192,365$ & rsds \\
Precipitation & $\mathrm{mm} \mathrm{d}^{-1}$ & $94 \times 192,12$ & $\mathrm{pr}$ \\
Wind $(u$ and $v$ components) & $\mathrm{m} \mathrm{s}^{-1}$ & $94 \times 192,1460$ & uas and vas \\
Temperature & $\mathrm{K}$ & $94 \times 192,1460$ & tas \\
Sea surface salinity & $\mathrm{psu}$ & $180 \times 360,12$ & $\mathrm{sos}$ \\
\hline
\end{tabular}

Table 2. PMIP3 models used in this study.

\begin{tabular}{llll}
\hline Model name & Modelling group & Reference & Source data reference \\
\hline CNRM-CM5 & CNRM-CERFACS (France) & Voldoire et al. (2013) & $\begin{array}{l}\text { piControl: Sénési et al. (2014a) } \\
\text { lgm: Sénési et al. (2014b) }\end{array}$ \\
\hline IPSL-CM5A-LR & IPSL (Institut Pierre Simon Laplace, France) & Dufresne et al. (2013) & $\begin{array}{l}\text { piControl: Caubel et al. (2016) } \\
\text { lgm: Kageyama et al. (2016) }\end{array}$ \\
\hline MIROC-ESM & MIROC (JAMSTEC and NIES, Japan) & Sueyoshi et al. (2013) & $\begin{array}{l}\text { piControl: JAMSTEC et al. (2015a) } \\
\text { lgm: JAMSTEC et al. (2015b) }\end{array}$ \\
\hline MRI-CGCM3 & MRI (Meteorological Research Institute, Japan) & Yukimoto et al. (2012) & $\begin{array}{l}\text { piControl: Yukimoto et al. (2015a) } \\
\text { lgm: Yukimoto et al. (2015b) }\end{array}$ \\
\hline GISS-E2-R & NASA/GISS (Goddard Institute for Space Stud- & Schmidt et al. (2014) & $\begin{array}{l}\text { piControl: NASA-GISS (2014a) } \\
\text { lgm: NASA-GISS (2014b) }\end{array}$ \\
\hline
\end{tabular}

a figure of each variable's annual mean anomaly and model spread. Alongside the lgm-piControl anomaly for each variable, the model spread across all five models has been made available. The individual model anomalies for each of the variables are presented in Fig. A1. In order to give the reader the opportunity to compare the anomaly data with typical pre-industrial values for each of the variables, we provide the multi-model annual mean for the piControl experiment in Fig. A2.

The inter-model disagreement is described for each variable in Sect. 3 and could, for example, be used to guide adjustments to the amplitude of the forcing anomaly for model tuning purposes. Additionally, proxy-based reconstructions are available for some of the variables, which can constrain potential adjustments to the forcing anomaly fields. We note, however, that for none of our variables does a purely proxybased global reconstruction exist - underlining the value of model-based reconstructions. A combination of model and proxy data makes it feasible to create global coverage for air temperatures (e.g. Annan and Hargreaves, 2013), but we are not aware of similar efforts for any of our other variables. Regional proxy-based reconstructions, although mostly quantitative and only over the continents, exist for humidity (e.g. Alexandre et al., 2018), precipitation (e.g. Mendes et al.,
Table 3. Package commands applied in this study. Detailed information on these commands can be found in the respective netCDF Operator (NCO) and Climate Data Operator (CDO) documentation online. All operations were performed with either $\mathrm{CDO}$ version 1.9.3 (Schulzweida, 2019) or NCO version 4.6.9. The complete list of commands is available in the NetCDF files under global attribute "history".

\begin{tabular}{ll}
\hline$\#$ & CDO or NCO command \\
\hline 1 & cdo remapbil,t62grid \\
2 & cdo ensmean \\
3 & cdo sub \\
4 & cdo setmisstodis \\
5 & ncap2 \\
6 & cdo inttime \\
\hline
\end{tabular}

2019), and wind direction and strength (e.g. Markewich et al., 2015). Regarding ocean proxies, salinity reconstructions are highly uncertain (Rohling, 2000) but could also provide some constraint to the model data. We leave the decision to the individual modelling groups whether to adjust their forcing fields for their specific application. 
All operations were performed with NetCDF toolkits Climate Data Operator (CDO) version 1.9.3 (Schulzweida, 2019) or netCDF Operator (NCO) version 4.6.9. The main functions used are documented in Table 3 and referred to in the text at the first occurrence. The atmospheric anomaly data are on a Gaussian grid with $94 \times 192$ (lat $\times$ long) grid points. The SSS fields are on a regular $180 \times 360$ (lat $\times$ long) grid. Regridding any of the files to a different model grid should be straightforward (e.g. Table 3,\#1) as it was ensured that all files contain the information needed for re-gridding. The variables, grid, and time resolution are chosen to be compatible with the CORE forcing fields (Large and Yeager, 2004), which have been extensively used in the ocean modelling community as they are the standard in ocean model comparisons (Griffies et al., 2009, 2016). We anticipate that the variables selected here should be useful in different model set-ups as well. We intend to provide a dataset that is flexible with respect to the use of different land-ocean masks in different models. Therefore, we account for changes in sea level (i.e. a larger land area in the LGM) which can affect variables in coastline areas by applying the following masking procedure: (i) masking the multi-model mean anomaly with the maximum lgm land mask across all models, then (ii) extrapolating the variable over land using a distance-weighted average (Table 3, \#4), and (iii) finally masking the data with a present-day land mask (based on the World Ocean Atlas $20131^{\circ}$ resolution land mask) but with the ocean extended in a $1.5^{\circ}$ radius over land. Therefore, our anomaly forcing dataset can likely be used with any pre-industrial land-sea mask. By following this procedure, the grid points affected by land-sea mask changes are thus filled with the extrapolated model mean anomaly from the LGM coastal ocean. In the case of NorESM-OC (Schwinger et al., 2016), the atmospheric anomaly fields were added to its CORE-NYF fields (Large and Yeager, 2004) to obtain an LGM normal-year forcing under the assumption of unchanged spatial and temporal variability for the respective variable. Note that the addition of the anomaly fields to the user's own model forcing could lead to physically unrealistic and/or non-meaningful results for some variables (such as negative precipitation or radiation). This must be corrected for by capping off sub-zero values (Table 3, \#5) after the addition of the anomaly.

\section{The variables}

\subsection{Specific humidity anomaly}

The mean anomaly of near-surface specific humidity over the five models was time interpolated (Table 3, \#6) to a 6-hour time resolution from the monthly climatological PMIP3 output. The annual mean lgm-piControl anomaly field (Fig. 1a) shows a global decrease in specific humidity, as would be expected from decreased air temperatures (Sect. 3.6). The anomaly is most pronounced around the Equator where we see a decrease of $2-3 \times 10^{-3} \mathrm{~kg} \mathrm{~kg}^{-1}$, while the anomaly is nearly zero towards both poles. The model spread of the anomaly shows a disagreement between the PMIP3 models generally in the order of $1-2 \times 10^{-3} \mathrm{~kg} \mathrm{~kg}^{-1}$, but it is larger (up to $4 \times 10^{-3} \mathrm{~kg} \mathrm{~kg}^{-1}$ ) in the Northern Hemisphere's western boundary current regions and close to the Arctic ice edge (Fig. 1b).

\subsection{Downwelling long-wave radiation anomaly}

The anomaly for surface downwelling long-wave radiation is time-interpolated (Table 3, \#6) to a daily time resolution. The annual mean anomaly field (Fig. 2a) shows globally decreased downwelling long-wave radiation in the lgm experiment compared to the piControl experiment in the order of $10-30 \mathrm{~W} \mathrm{~m}^{-2}$ over most of the ocean due to a generally cooler atmosphere (Sect. 3.6). The largest anomalies lie close to the northern ice sheets with up to $-90 \mathrm{~W} \mathrm{~m}^{-2}$ lower radiation in the lgm experiment than in the piControl experiment. Ice is likely also the main contributor to the high $\left(60-90 \mathrm{~W} \mathrm{~m}^{-2}\right)$ inter-model spread in the North Atlantic and Southern oceans (Fig. A3). The remainder of the ocean exhibits a better agreement with inter-model spreads generally below $20 \mathrm{~W} \mathrm{~m}^{-2}$ (Fig. 2b).

\subsection{Downwelling short-wave radiation anomaly}

The surface downwelling short-wave radiation anomaly field is time-interpolated (Table 3, \#6) to daily fields as was done for downwelling long-wave radiation. The annual mean anomaly is especially pronounced around the Laurentide and Scandinavian ice sheets, where strong positive anomalies of over $\sim 30 \mathrm{~W} \mathrm{~m}^{-2}$ exist (Fig. 3a). Globally, the annual mean downwelling short-wave radiation anomaly generally falls in a range of -15 to $+15 \mathrm{~W} \mathrm{~m}^{-2}$ over the ocean. The anomaly field shows negative anomalies and positive ones in an alternating spatial pattern approximately symmetrical around the Equator in the Pacific basin. The inter-model spread is largest in the North Atlantic region and along the Equator (Fig. 3b). Due to the large model disagreement of up to $50 \mathrm{~W} \mathrm{~m}^{-2}$ for this variable (Fig. 3), the inter-model spread and mean anomaly are of similar magnitude, although a consistent pattern is present in the anomaly field.

\subsection{Precipitation anomaly and river run-off}

The anomaly precipitation presented here is the lgmpiControl anomaly at the air-sea interface and includes both the liquid and solid phases from all types of clouds (both large-scale and convective). The units were converted to millimetres per day $\left(\mathrm{mm} \mathrm{d}^{-1}\right)$ to comply with the CORE forcing format (causing a deviation from the Climate and Forecast Convention 1.6). The resulting annual mean anomaly generally falls in the range of -2 to $2 \mathrm{~mm} \mathrm{~d}^{-1}$ and is most pronounced along the Equator (Fig. 4a). The models show a mean increase in precipitation directly south of the Equator 
(ต)

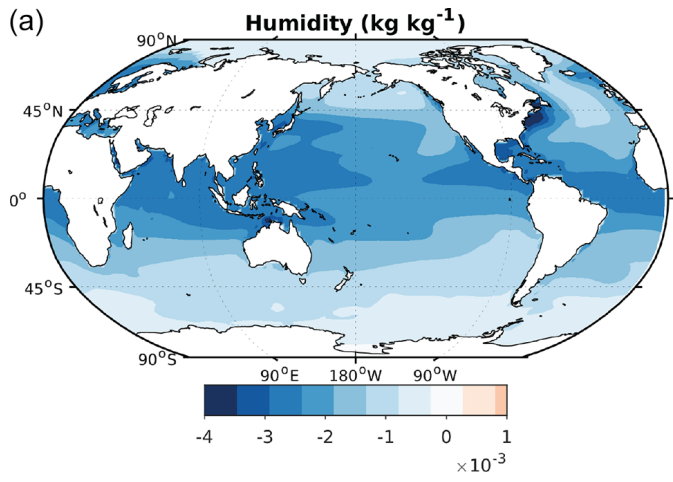

(b)

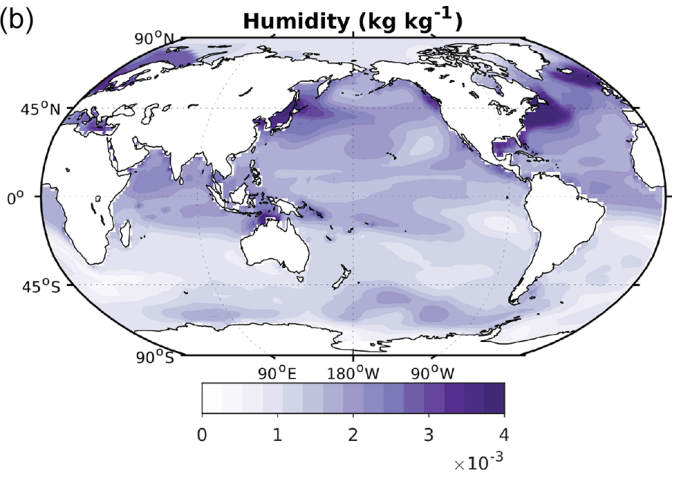

Figure 1. Annual mean specific humidity lgm-piControl anomaly (a) and model spread (b) (in kg kg${ }^{-1}$ ).
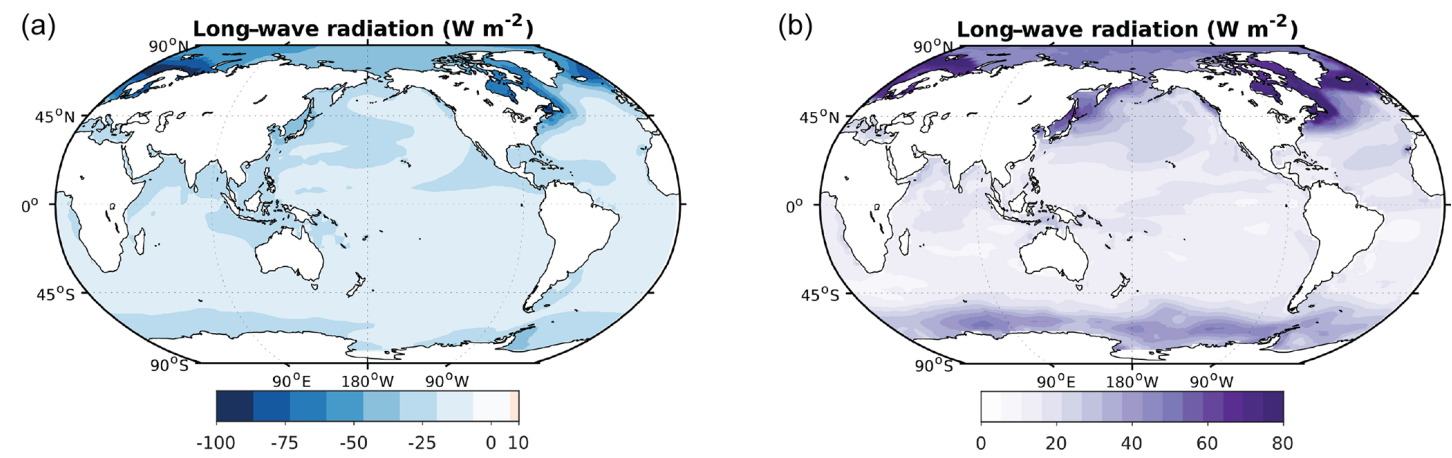

Figure 2. Annual mean downwelling long-wave radiation lgm-piControl anomaly (a) and model spread (b) (in $\mathrm{W} \mathrm{m}^{-2}$ ).

in the Pacific basin, as well as in the Pacific subtropics off the western North American coast. The North Atlantic also receives a mean positive precipitation anomaly, offsetting part of the positive salinity anomaly there, which is potentially relevant for the simulation of deepwater formation in this region (Sect. 3.7). Negative mean precipitation anomalies are most pronounced directly north of the Equator and north of $\sim 40^{\circ} \mathrm{N}$ in the Pacific basin, as well as in the Atlantic Arctic. The inter-model spread is up to $\sim 5 \mathrm{~mm} \mathrm{~d}^{-1}$ around the Equator, likely due to the model disagreement about the sign and location of changes in the inter-tropical convergence zone (Fig. 4b). Related to precipitation fluxes, river run-off fluxes also changed between the lgm and piControl model experiments. As land-sea masks and river routing are very model specific, we can not provide a gridded river run-off anomaly. Instead, we provide mean absolute and relative large-scale river run-off changes integrated over ocean basins (North/South Atlantic, North/South Pacific, Indian Ocean; Table 4). These anomalies can be used by modelling groups to scale pre-industrial river run-off. Note that evaporation simulated by a forced ocean model will generally not equal the sum of the prescribed precipitation and river run-off. For long integrations, it is therefore necessary to adjust one (or both) of these forcings to close the freshwater balance and avoid salinity drift. We assume that mod- elling groups employing our anomaly forcing will have such a mechanism suitable for their model in place.

\subsection{Wind anomalies: $u$ and $v$ components}

Both for the $u$ and $v$ component of the wind speed, the lgmpiControl anomaly is time-interpolated to 6-hourly fields. The annual mean meridional wind velocity ( $v$, southerly winds) anomaly shows a pronounced increase $\left(\sim 3-5 \mathrm{~m} \mathrm{~s}^{-1}\right)$ in southerly winds around the north-western edge of the Laurentide Ice Sheet, as well as over the north-western edge of the Scandinavian Ice Sheet (Fig. 5a). Alongside that, a pronounced decrease $\left(\sim 3-5 \mathrm{~m} \mathrm{~s}^{-1}\right)$ in southerly winds is simulated along the eastern North American coast and the Canadian Archipelago. The open ocean anomalies are generally small (at most $\pm 1 \mathrm{~m} \mathrm{~s}^{-1}$ ). The inter-model spread has no pronounced pattern but is sizable with $\sim 1-5 \mathrm{~m} \mathrm{~s}^{-1}$ disagreement between the PMIP3 models (Fig. 5b). The mean zonal wind velocity ( $u$, westerly winds) anomaly shows alternating negative and positive anomaly bands with an approximate $\pm 2 \mathrm{~m} \mathrm{~s}^{-1}$ range (Fig. 6a). This pattern is stronger in the Northern Hemisphere north of $\sim 45^{\circ} \mathrm{N}$. The intermodel spread $\left(\sim 1-3 \mathrm{~m} \mathrm{~s}^{-1}\right)$ has little structure except for the $\sim 4-5 \mathrm{~m} \mathrm{~s}^{-1}$ disagreement in the Southern Ocean south of $\sim 40^{\circ} \mathrm{S}$ and the $\sim 3-5 \mathrm{~m} \mathrm{~s}^{-1}$ disagreement in the North Atlantic (Fig. 6b). In the Southern Ocean, the band of large dis- 
(a)

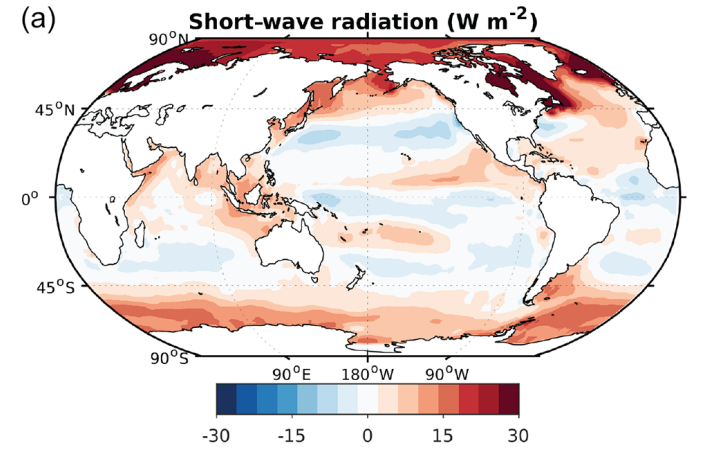

(b)

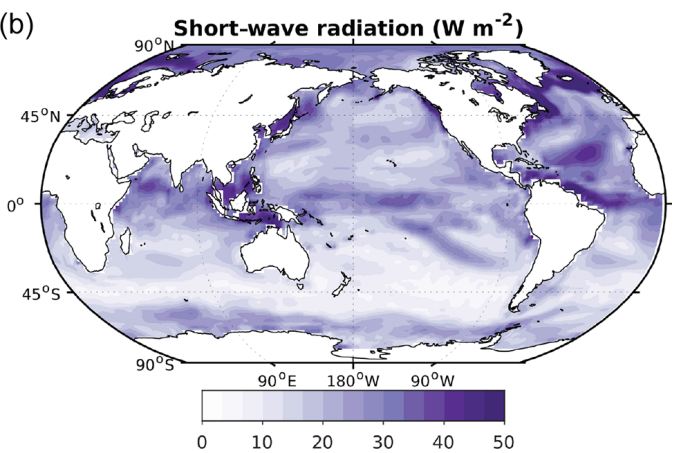

Figure 3. Annual mean downwelling short-wave radiation lgm-piControl anomaly (a) and model spread (b) (in $\mathrm{W} \mathrm{m}^{-2}$ ).
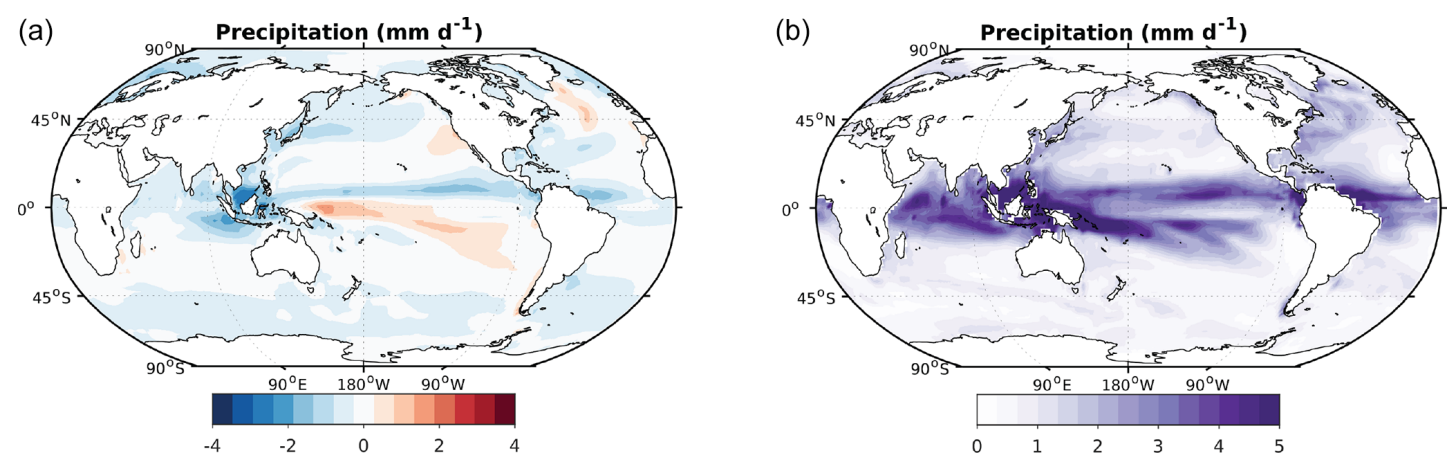

Figure 4. Annual mean precipitation lgm-piControl anomaly (a) and model spread (b) (in $\mathrm{mm} \mathrm{d}^{-1}$ ).

agreement in westerly wind speeds reflects the large uncertainty in the simulated position of the Southern Hemisphere's jet stream, both in pre-industrial times and the LGM. This disagreement is reinforced by the fact that shifts in the jet position between pre-industrial times and the LGM also depend on the simulated expansion of sea ice (Sime et al. 2016; Fig. A3).

\subsection{Temperature anomaly}

The near-surface atmospheric temperature is timeinterpolated to calculate the 6-hourly mean anomaly for temperature. The annual mean anomaly is most pronounced in the North Atlantic, where open ocean anomalies exceed $-10 \mathrm{~K}$. Elsewhere, the annual mean temperature anomaly is $\sim-2.5 \mathrm{~K}$ (Fig. 7a). There is a clear pattern in the model spread: the models show a large spread $(>10 \mathrm{~K})$ north of $\sim 45^{\circ} \mathrm{N}$, as well as south of $\sim 50^{\circ} \mathrm{S}(5-10 \mathrm{~K})$, likely due to the disagreement about ice cover (Fig. A3). At lower latitudes, the model spread is generally smaller (0-3 K) (Fig. 7b).

\subsection{Sea surface salinity anomaly}

Global mean salinity is initialized in PMIP3 models with a 1 psu higher salinity to account for the concentrating effect of the decrease in sea level (Kageyama et al., 2017). Sea sur- face salinity, however, shows a more variable annual mean lgm-piControl change due to changes in the global hydrological cycle (Fig. 8). The sea surface salinity anomaly is presented on a regular $1 \times 1$ grid for ease of use. The resulting annual mean SSS anomaly (Fig. 8a) shows an increase in sea surface salinity $(\sim 1 \mathrm{psu})$ over the Southern Ocean south of $\sim 55^{\circ} \mathrm{S}$, as well as in the Arctic (>3 psu) and the northern Indian Ocean $(\sim 1 \mathrm{psu})$. A $\sim 2$ psu anomaly is simulated in the Canadian Archipelago, the Labrador Sea, and across the North Atlantic between what is now Canada and Europe (Fig. 8a). Freshening is simulated close to some continents and is especially pronounced around Scandinavia (about $-3 \mathrm{psu}$ ). Simulated ocean circulation can be very sensitive to fresh water forcing and thus SSS, especially in the North Atlantic (e.g. Rahmstorf, 1996; Spence et al., 2008). Applications of SSS restoring using the SSS anomaly field should therefore be done with caution and attention to its effects on the meridional overturning circulation. The tuning of the salinity anomaly in important deepwater formation regions of up to about \pm 1 psu, such as done by, for example, Winguth et al. (1999), may be required to obtain a satisfactory circulation field in reasonable agreement with proxy data. Such adjustments fall well within the PMIP3 model spread (Fig. 8b) and show the current limitations of fully coupled PMIP3 models in simulating an LGM hydrological cycle consistent with proxy records of ocean circulation. 
(a)

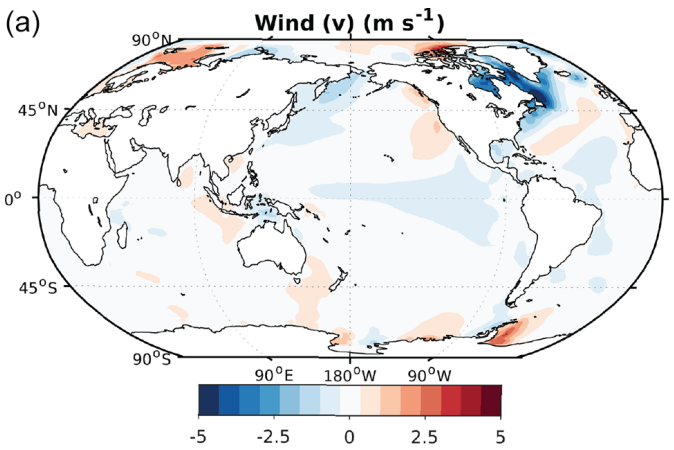

(b)

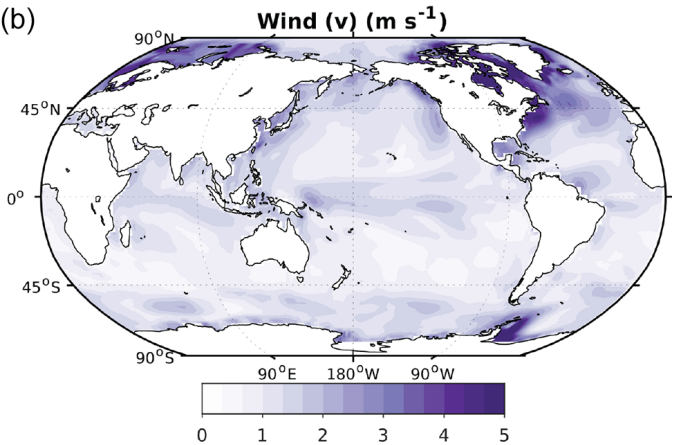

Figure 5. Annual mean meridional wind velocity lgm-piControl anomaly (a) and model spread (b) (in $\mathrm{m} \mathrm{s}^{-1}$ ).
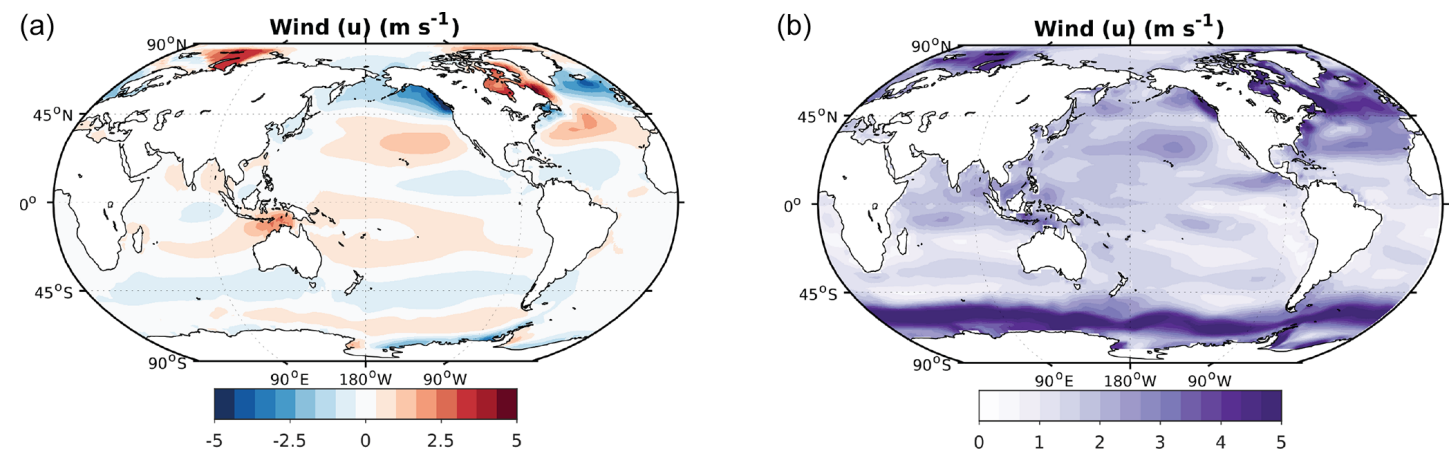

Figure 6. Annual mean zonal wind velocity lgm-piControl anomaly (a) and model spread (b) (in $\mathrm{m} \mathrm{s}^{-1}$ ).

\section{Limitations of the dataset}

The anomaly fields presented here are a model-based "best estimate" of the LGM anomaly relative to the pre-industrial state. There are some important limitations to these data related to the temporal resolution, the use of model means, and the fact that we rely on modelling results only.

Proxy data with global coverage are unavailable for most of the variables needed to force stand-alone ocean models. We do not attempt to constrain the anomaly fields using the spatially limited information from available proxy data. Consequently, where PMIP3 models are in disagreement with proxy data, our dataset will be so, too. The limitations (or uncertainty) of the PMIP3 simulations can be seen through the large inter-model spread which is provided with the anomaly data. This does not preclude the possibility that PMIP3 models collectively (i.e. such that the model spread is small) disagree with available proxy data. Nevertheless, PMIP3 is the state of the art for the modelling of past climates at present (Braconnot et al., 2012; Braconnot and Kageyama, 2015).

By adding multi-model mean anomalies to forcing fields, dynamical inconsistencies (e.g. between wind and temperature fields) will be created. This means that the resulting forcing fields do not strictly obey the equations of state or motion. A forcing dataset would typically be dynamically consistent if the forcing would be the outcome of an atmospheric model or an advanced reanalysis. The advantage of using model mean fields is that large anomalies of individual models will be smoothed out where models disagree. We believe that currently a main challenge for palaeo-modelling activities is to achieve integration times that are long enough. Therefore, using a single forcing (as opposed to using multiple forcings from individual models) seems to be preferable. Regarding the dynamical inconsistencies, it is important to note that the CORE forcing itself (for which our dataset is optimized) is a mixture of reanalysis and observational data products and as such not dynamically consistent.

PMIP3 model output is publicly available only as monthly mean fields, which also results in some limitations for the anomaly forcing dataset. First, although we interpolate the monthly mean anomaly fields to a higher (e.g. 6-hourly) temporal resolution, we implicitly assume that any sub-monthly variability (e.g. the diurnal cycle) is preserved from the preindustrial climate state to the LGM state. We can currently not quantify the implications of this assumption, but future phases of PMIP (providing simulation output with higher temporal resolution) might alleviate this problem. Second, we are not able to accurately re-reference near-surface temperature and humidity to a different reference height. The CORE bulk forcing method of Large and Yeager (2004) requires near-surface specific humidity and temperature at the same height as the wind forcing (at $10 \mathrm{~m}$ ). Humidity and temperature are, however, provided at $2 \mathrm{~m}$ height in PMIP3 (as in most atmospheric data products). A procedure to re-reference 
(a)

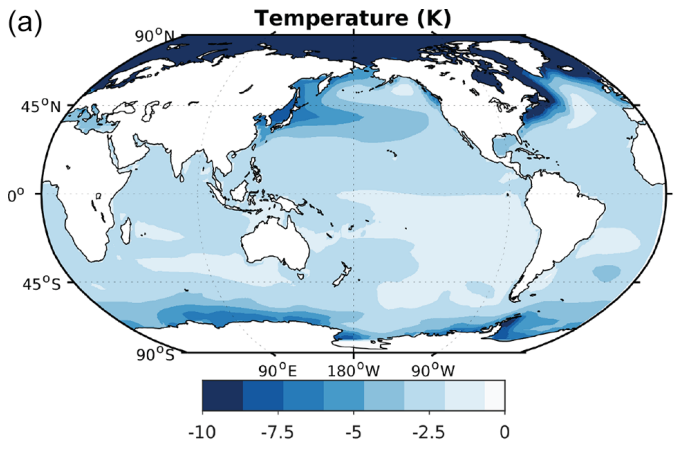

(b)

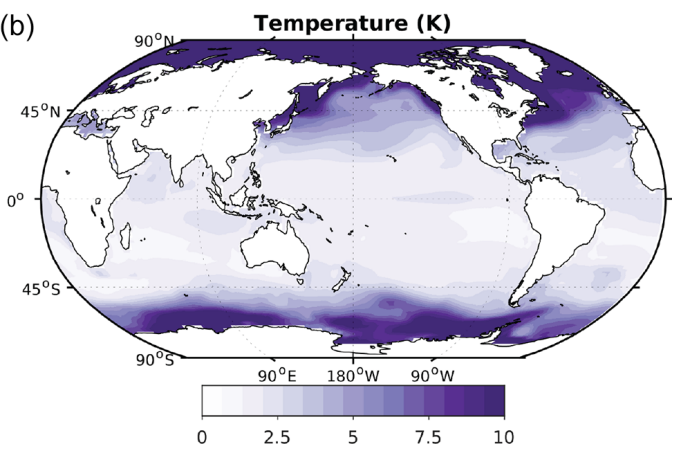

Figure 7. Annual mean temperature lgm-piControl anomaly (a) and model spread (b) (in K).
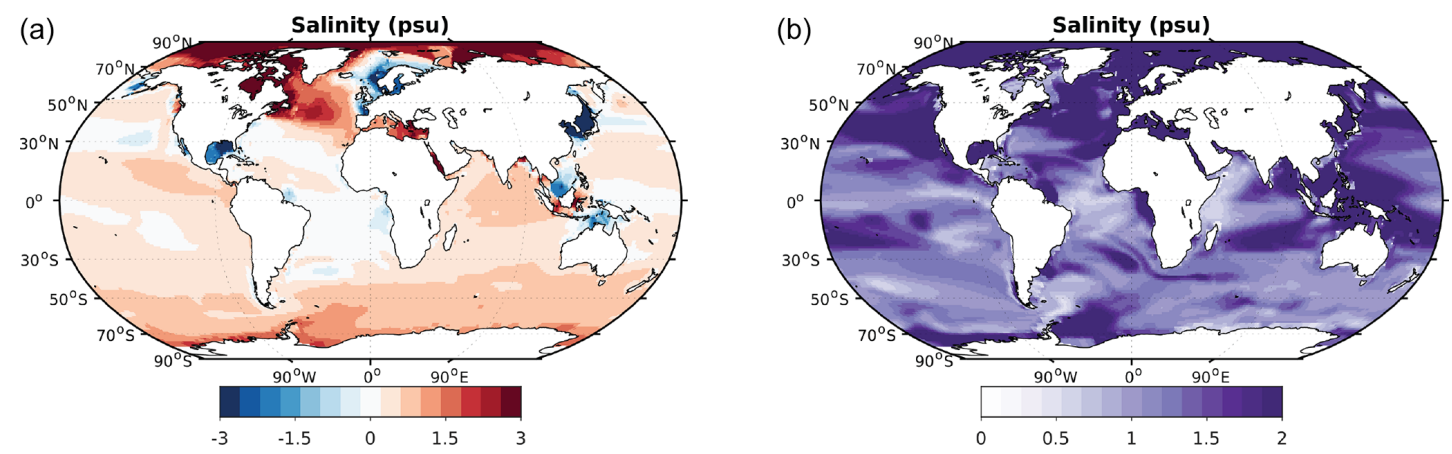

Figure 8. Annual mean sea surface salinity lgm-piControl anomaly (a) and model spread (b) (in psu).

humidity and temperature from 2 to $10 \mathrm{~m}$ (e.g. Large and Yeager, 2004) requires input data at a higher (sub-daily) time resolution in order to resolve different boundary layer stability regimes. However, for an anomaly forcing, the rereferencing only has an effect if it leads to different temperature and/or humidity increments under the PI and the LGM state. For the open ocean, this is barely the case, and taking a climatological anomaly of $2 \mathrm{~m}$ quantities and applying it at $10 \mathrm{~m}$ height is unproblematic. Over sea ice, however, there could be a larger effect of the re-referencing (due to a significantly different atmospheric stability in the LGM state), especially regarding the temperature. Our analysis indicates that this is probably the case over the central Arctic Ocean (not shown). For all other regions, we estimate that the error made in applying the re-referencing approach on monthly climatological-resolved data does not justify its application. In general, the error made by omitting the re-referencing is much smaller than the uncertainties of the anomalies (i.e. the model spread), particularly at high latitudes.

Regarding the robustness of the dataset, we observe that the inclusion of additional model data only leads to minor changes in the anomalies. An example of this is given by comparing version 1 (Morée and Schwinger, 2019) and the current version 3 (Morée and Schwinger, 2020) of this dataset, as the latter also includes the GISS-E2-R model for the calculation of the anomalies. Indeed, individual model anomalies (Fig. A1) show broad agreement, although the magnitude of the anomaly is less agreed on (as discussed in more detail for the individual variables in Sect. 3).

Despite the limitations described here, we believe that using the mean PMIP3 anomaly of coupled models as forcing is currently the best available option for use in standalone ocean models. For this purpose, our dataset provides lgm-piControl anomalies in standardized format for the most common variables used in ocean forcing.

\section{Data availability}

The data are publicly accessible at the NIRD Research Data Archive at https://doi.org/10.11582/2020.00052 (Morée and Schwinger, 2020). The .md5 files contain an md5 checksum, which can be used to check whether changes have been made to the respective NetCDF files.

\section{Summary and conclusions}

The output of the fully coupled PMIP3 simulations of CNRM-CM5, IPSL-CM5A-LR, MIROC-ESM, MRICGCM3 and GISS-E2-R is converted to anomaly datasets intended for use in forced ocean modelling of the LGM. All anomalies are calculated as the difference between the "lgm" and "piControl" PMIP3 experiments. In addition, all data are formatted in a way that further conversions (of, for example, units or the grid) can be applied in a straightforward way. The 


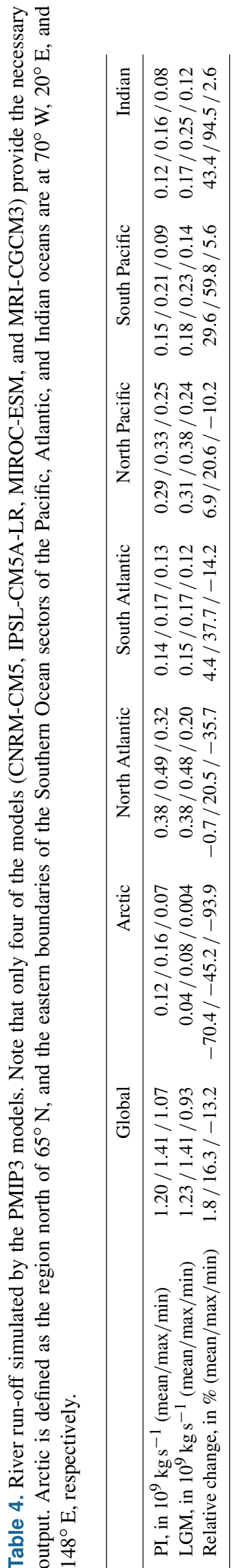

variables are provided in NetCDF format in separate files and distributed by the NIRD Research Data Archive (Morée and Schwinger, 2020). A climatological LGM forcing dataset can be created for any forced ocean model by the addition of the presented 2-D anomaly fields to the model's pre-industrial forcing. This approach enables the scientific community to simulate the LGM ocean state in a forced ocean model setup. We expect that if additional forcing is needed for a specific model, the same approach as described above can be followed. This process is simplified by providing all main CDO and NCO commands used in creating the dataset (Table 3). All data represent a climatological year, i.e. one annual cycle per variable. The application of the data is thus suitable for "time-slice" equilibrium simulations of the LGM and optimized for use with the CORE forcing format (Large and Yeager, 2004).

The uncertainty of our anomaly forcing (approximated by the model spread of the PMIP3 models) is generally of similar magnitude as the multi-model annual mean. The complete attribution of the model spread to specific processes is beyond the scope of this article, but our results show that there is considerable uncertainty involved in the magnitude of the anomaly for all variables presented here. Nevertheless, all mean anomalies show a distinct spatial pattern that we expect to be indicative of the LGM-PI changes. Finally, there is currently no other way to reconstruct most of these variables than model simulations with state-of-the-art Earth system models such as those applied in the PMIP3 experiments. For modelling purposes, the inter-model disagreement of PMIP3 provides the user with leeway to adjust the amplitude of the forcing (guided by the size of the model spread, which is therefore provided alongside the variables in the dataset). Such adjustments can improve model-proxy data agreements, such as those described for salinity in Sect. 3.7. 
Appendix A

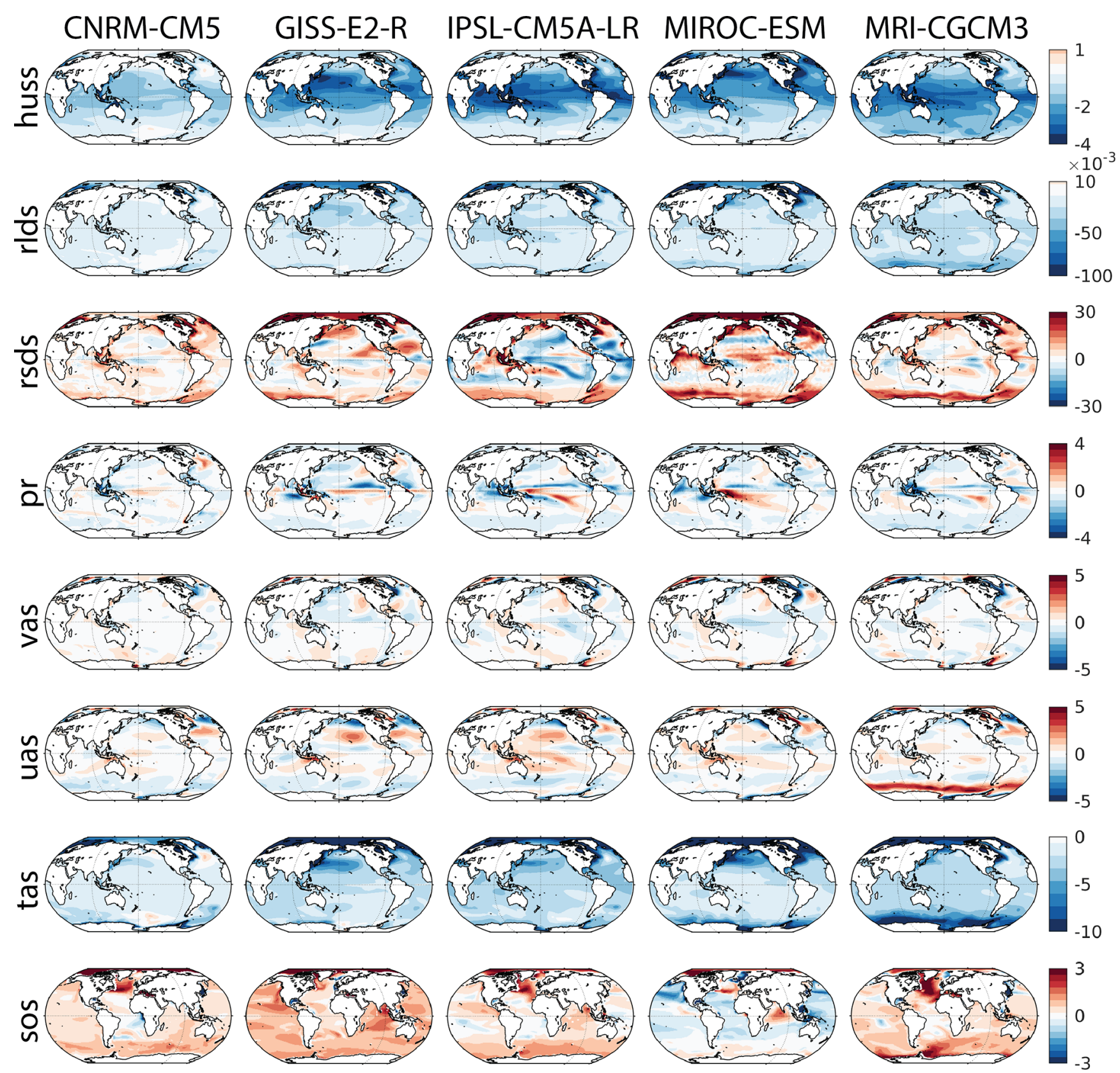

Figure A1. Annual mean individual model anomalies for each of the variables (see Table 1) and models in the dataset. Units are the same as in the remainder of this paper. 

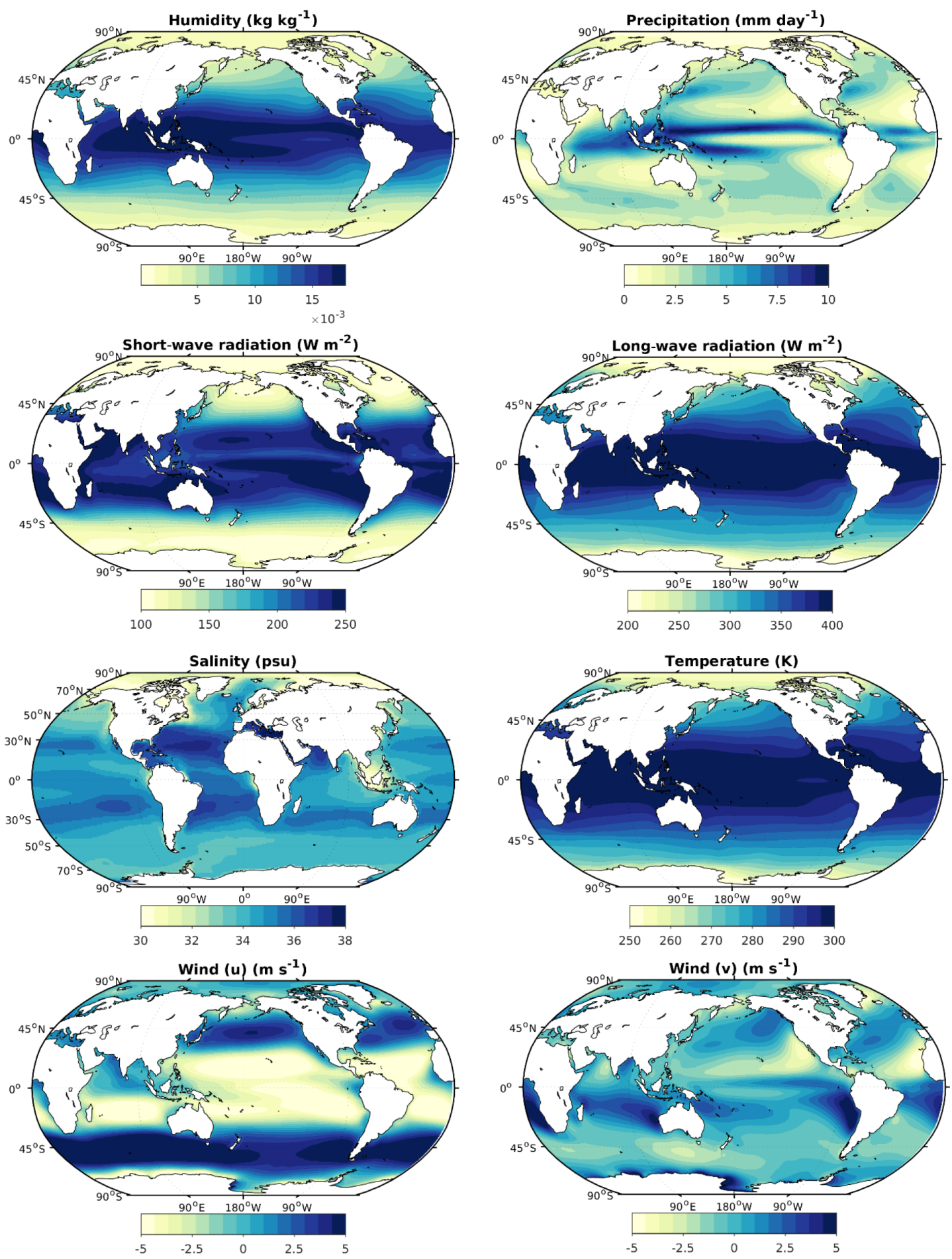

Figure A2. Annual mean for each of the variables (see Table 1) for the piControl CMIP5/PMIP3 experiment. 


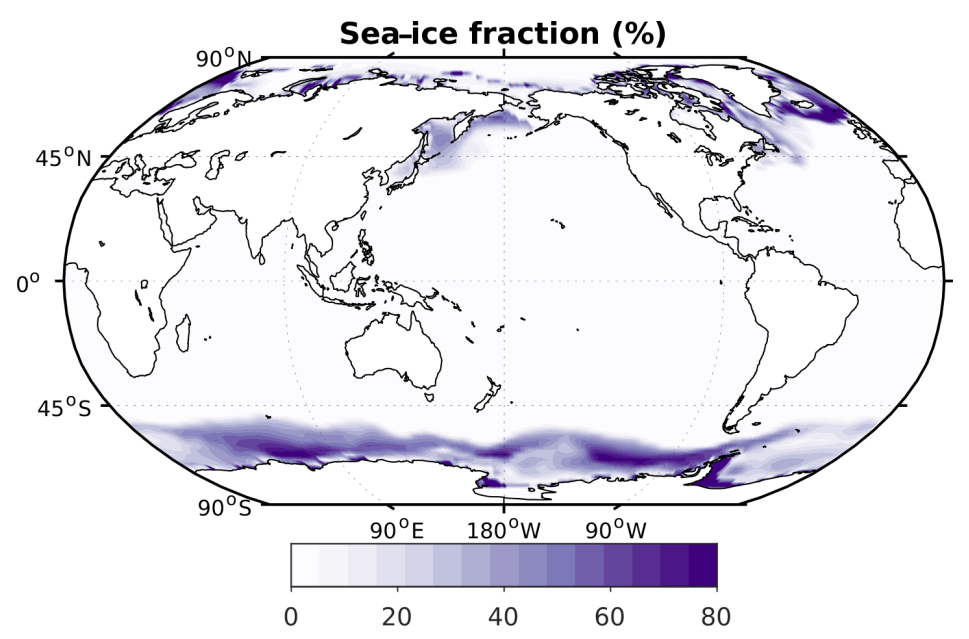

Figure A3. Annual mean model spread of sea-ice fraction. 
Author contributions. ALM prepared, visualized, and analysed the data and wrote the original draft of the paper. ALM and JS together conceptualized the method and revised the paper. JS provided supervision throughout the study.

Competing interests. The authors declare that they have no conflict of interest.

Acknowledgements. We acknowledge the World Climate Research Programme's Working Group on Coupled Modelling, which is responsible for CMIP, and we thank the climate modelling groups (Table 2) for producing and making available their model output. For CMIP, the US Department of Energy's Program for Climate Model Diagnosis and Intercomparison provides coordinating support and led development of software infrastructure in partnership with the Global Organization for Earth System Science Portals. This is a contribution to the Bjerknes Centre for Climate Research (Bergen, Norway). Storage resources were provided by UNINETT Sigma2 - the National Infrastructure for High Performance Computing and Data Storage in Norway (project number ns2980k). The authors thank four anonymous reviewers and Editor Kirsten Elger for their valuable feedback on our paper.

Financial support. This research has been supported by CRESCENDO (Coordinated Research in Earth Systems and Climate: Experiments, kNowledge, Dissemination and Outreach; European Commission's Horizon 2020 European Union Framework Programme for Research and Innovation, grant no. 641816) and the Research Council of Norway (project INES 270061). Anne L. Morée is grateful for PhD funding through the Faculty for Mathematics and Natural Sciences of the University of Bergen (UoB), as well as support by the Meltzer fund of UoB and Erasmus Mundus to stay at ETH Zürich for part of this work.

Review statement. This paper was edited by Kirsten Elger and reviewed by four anonymous referees.

\section{References}

Alexandre, A., Landais, A., Vallet-Coulomb, C., Piel, C., Devidal, S., Pauchet, S., Sonzogni, C., Couapel, M., Pasturel, M., Cornuault, P., Xin, J., Mazur, J.-C., Prié, F., Bentaleb, I., Webb, E., Chalié, F., and Roy, J.: The triple oxygen isotope composition of phytoliths as a proxy of continental atmospheric humidity: insights from climate chamber and climate transect calibrations, Biogeosciences, 15, 3223-3241, https://doi.org/10.5194/bg-153223-2018, 2018.

Annan, J. D. and Hargreaves, J. C.: A new global reconstruction of temperature changes at the Last Glacial Maximum, Clim. Past, 9, 367-376, https://doi.org/10.5194/cp-9-367-2013, 2013.

Bouttes, N., Paillard, D., Roche, D. M., Brovkin, V., and Bopp, L.: Last Glacial Maximum $\mathrm{CO}_{2}$ and $\delta 13 \mathrm{C}$ successfully reconciled, Geophys. Res. Lett., 38, L02705, https://doi.org/10.1029/2010GL044499, 2011.
Braconnot, P. and Kageyama, M.: Shortwave forcing and feedbacks in Last Glacial Maximum and Mid-Holocene PMIP3 simulations, Philos. T. Roy. Soc. A, 373, 20140424, https://doi.org/10.1098/rsta.2014.0424, 2015.

Braconnot, P., Otto-Bliesner, B., Harrison, S., Joussaume, S., Peterchmitt, J.-Y., Abe-Ouchi, A., Crucifix, M., Driesschaert, E., Fichefet, Th., Hewitt, C. D., Kageyama, M., Kitoh, A., Laîné, A., Loutre, M.-F., Marti, O., Merkel, U., Ramstein, G., Valdes, P., Weber, S. L., Yu, Y., and Zhao, Y.: Results of PMIP2 coupled simulations of the Mid-Holocene and Last Glacial Maximum Part 1: experiments and large-scale features, Clim. Past, 3, 261 277, https://doi.org/10.5194/cp-3-261-2007, 2007.

Braconnot, P., Harrison, S., Kageyama, M., Bartlein, P., Masson-Delmotte, V., Abe-Ouchi, A., Otto-Bliesner, B., and Zhao, Y.: Evaluation of climate models using palaeoclimatic data, Nat. Clim. Change, 2, 417-424, https://doi.org/10.1038/nclimate1456, 2012.

Brady, E. C., Otto-Bliesner, B. L., Kay, J. E., and Rosenbloom, N.: Sensitivity to Glacial Forcing in the CCSM4, J. Climate, 26, 1901-1925, https://doi.org/10.1175/JCLI-D-11-00416.1, 2012.

Buchanan, P. J., Matear, R. J., Lenton, A., Phipps, S. J., Chase, Z., and Etheridge, D. M.: The simulated climate of the Last Glacial Maximum and insights into the global marine carbon cycle, Clim. Past, 12, 2271-2295, https://doi.org/10.5194/cp-122271-2016, 2016.

Caubel, A., Denvil, S., Foujols, M. A., Marti, O., Dufresne, J.-L., Bopp, L., Cadule, P., Ethé, C., Idelkadi, A., Mancip, M., Masson, S., Mignot, J., Ionela, M., Balkanski, Y., Bekki, S., Bony, S., Braconnot, P., Brockman, P., Codron, F., Cozic, A., Cugnet, D., Fairhead, L., Fichefet, T., Flavoni, S., Guez, L., Guilyardi, E., Hourdin, F., Ghattas, J., Kageyama, M., Khodri, M., Labetoulle, S., Lefebvre, M.-P., Levy, C., Li, L., Lott, F., Madec, G., Marchand, M., Meurdesoif, Y., Rio, C., Schulz, M., Swingedouw, D., Szopa, S., Viovy, N., and Vuichard, N.: IPSL-CM5A-LR model output prepared for CMIP5 piControl experiment, served by ESGF, WDCC at DKRZ, https://doi.org/10.1594/WDCC/CMIP5.IPILpc, 2016.

Dufresne, J. L., Foujols, M. A., Denvil, S., Caubel, A., Marti, O., Aumont, O., Balkanski, Y., Bekki, S., Bellenger, H., Benshila, R., Bony, S., Bopp, L., Braconnot, P., Brockmann, P., Cadule, P., Cheruy, F., Codron, F., Cozic, A., Cugnet, D., de Noblet, N., Duvel, J. P., Ethé, C., Fairhead, L., Fichefet, T., Flavoni, S., Friedlingstein, P., Grandpeix, J. Y., Guez, L., Guilyardi, E., Hauglustaine, D., Hourdin, F., Idelkadi, A., Ghattas, J., Joussaume, S., Kageyama, M., Krinner, G., Labetoulle, S., Lahellec, A., Lefebvre, M. P., Lefevre, F., Levy, C., Li, Z. X., Lloyd, J., Lott, F., Madec, G., Mancip, M., Marchand, M., Masson, S., Meurdesoif, Y., Mignot, J., Musat, I., Parouty, S., Polcher, J., Rio, C., Schulz, M., Swingedouw, D., Szopa, S., Talandier, C., Terray, P., Viovy, N., and Vuichard, N.: Climate change projections using the IPSL-CM5 Earth System Model: from CMIP3 to CMIP5, Clim. Dynam., 40, 2123-2165, https://doi.org/10.1007/s00382012-1636-1, 2013.

Eyring, V., Bony, S., Meehl, G. A., Senior, C. A., Stevens, B., Stouffer, R. J., and Taylor, K. E.: Overview of the Coupled Model Intercomparison Project Phase 6 (CMIP6) experimental design and organization, Geosci. Model Dev., 9, 1937-1958, https://doi.org/10.5194/gmd-9-1937-2016, 2016. 
Griffies, S. M., Biastoch, A., Böning, C., Bryan, F., Danabasoglu, G., Chassignet, E. P., England, M. H., Gerdes, R., Haak, H., Hallberg, R. W., Hazeleger, W., Jungclaus, J., Large, W. G., Madec, G., Pirani, A., Samuels, B. L., Scheinert, M., Gupta, A. S., Severijns, C. A., Simmons, H. L., Treguier, A. M., Winton, M., Yeager, S., and Yin, J.: Coordinated Ocean-ice Reference Experiments (COREs), Ocean Model., 26, 1-46, https://doi.org/10.1016/j.ocemod.2008.08.007, 2009.

Griffies, S. M., Danabasoglu, G., Durack, P. J., Adcroft, A. J., Balaji, V., Böning, C. W., Chassignet, E. P., Curchitser, E., Deshayes, J., Drange, H., Fox-Kemper, B., Gleckler, P. J., Gregory, J. M., Haak, H., Hallberg, R. W., Heimbach, P., Hewitt, H. T., Holland, D. M., Ilyina, T., Jungclaus, J. H., Komuro, Y., Krasting, J. P., Large, W. G., Marsland, S. J., Masina, S., McDougall, T. J., Nurser, A. J. G., Orr, J. C., Pirani, A., Qiao, F., Stouffer, R. J., Taylor, K. E., Treguier, A. M., Tsujino, H., Uotila, P., Valdivieso, M., Wang, Q., Winton, M., and Yeager, S. G.: OMIP contribution to CMIP6: experimental and diagnostic protocol for the physical component of the Ocean Model Intercomparison Project, Geosci. Model Dev., 9, 3231-3296, https://doi.org/10.5194/gmd-9-32312016, 2016.

JAMSTEC, AORI, and NIES: MIROC-ESM model output prepared for CMIP5 piControl, served by ESGF, https://doi.org/10.1594/WDCC/CMIP5.MIMEpc, 2015a.

JAMSTEC, AORI, and NIES: MIROC-ESM model output prepared for CMIP5 lgm, served by ESGF, https://doi.org/10.1594/WDCC/CMIP5.MIMElg, 2015b.

Kageyama, M., Denvil, S., Foujols, M. A., Caubel, A., Marti, O., Dufresne, J.-L., Bopp, L., Cadule, P., Ethé, C., Idelkadi, A., Mancip, M., Masson, S., Mignot, J., Ionela, M., Balkanski, Y., Bekki, S., Bony, S., Braconnot, P., Brockman, P., Codron, F., Cozic, A., Cugnet, D., Fairhead, L., Fichefet, T., Flavoni, S., Guez, L., Guilyardi, E., Hourdin, F., Ghattas, J., Khodri, M., Labetoulle, S., Lefebvre, M.-P., Levy, C., Li, L., Lott, F., Madec, G., Marchand, M., Meurdesoif, Y., Rio, C., Schulz, M., Swingedouw, D., Szopa, S., Viovy, N., and Vuichard, N.: IPSL-CM5A-LR model output prepared for CMIP5 lgm experiment, served by ESGF, WDCC at DKRZ https://doi.org/10.1594/WDCC/CMIP5.IPILlg, 2016.

Kageyama, M., Albani, S., Braconnot, P., Harrison, S. P., Hopcroft, P. O., Ivanovic, R. F., Lambert, F., Marti, O., Peltier, W. R., Peterschmitt, J.-Y., Roche, D. M., Tarasov, L., Zhang, X., Brady, E. C., Haywood, A. M., LeGrande, A. N., Lunt, D. J., Mahowald, N. M., Mikolajewicz, U., Nisancioglu, K. H., Otto-Bliesner, B. L., Renssen, H., Tomas, R. A., Zhang, Q., Abe-Ouchi, A., Bartlein, P. J., Cao, J., Li, Q., Lohmann, G., Ohgaito, R., Shi, X., Volodin, E., Yoshida, K., Zhang, X., and Zheng, W.: The PMIP4 contribution to CMIP6 - Part 4: Scientific objectives and experimental design of the PMIP4-CMIP6 Last Glacial Maximum experiments and PMIP4 sensitivity experiments, Geosci. Model Dev., 10, 4035-4055, https://doi.org/10.5194/gmd-10-4035-2017, 2017.

Kageyama, M., Braconnot, P., Harrison, S. P., Haywood, A. M., Jungclaus, J. H., Otto-Bliesner, B. L., Peterschmitt, J.-Y., AbeOuchi, A., Albani, S., Bartlein, P. J., Brierley, C., Crucifix, M., Dolan, A., Fernandez-Donado, L., Fischer, H., Hopcroft, P. O., Ivanovic, R. F., Lambert, F., Lunt, D. J., Mahowald, N. M., Peltier, W. R., Phipps, S. J., Roche, D. M., Schmidt, G. A., Tarasov, L., Valdes, P. J., Zhang, Q., and Zhou, T.: The PMIP4 contribution to CMIP6 - Part 1: Overview and over- arching analysis plan, Geosci. Model Dev., 11, 1033-1057, https://doi.org/10.5194/gmd-11-1033-2018, 2018.

Khatiwala, S., Schmittner, A., and Muglia, J.: Air-sea disequilibrium enhances ocean carbon storage during glacial periods, Sci. Adv., 5, eaaw4981, https://doi.org/10.1126/sciadv.aaw4981, 2019.

Large, W. G. and Yeager, S. G.: Diurnal to decadal global forcing for ocean and sea-ice models: the data sets and flux climatologies, Tech. Note NCAR/TN-460+STR, National Center of Atmospheric Research, Boulder, Colorado, USA, available at: http://opensky.ucar.edu/islandora/object/technotes:434 (last access: 30 September 2020), 2004.

Lynch-Stieglitz, J., Ito, T., and Michel, E.: Antarctic density stratification and the strength of the circumpolar current during the Last Glacial Maximum, Paleoceanography, 31, 539-552, https://doi.org/10.1002/2015PA002915, 2016.

Markewich, H. W., Litwin, R. J., Wysocki, D. A., and Pavich, M. J.: Synthesis on Quaternary aeolian research in the unglaciated eastern United States, Aeolian Res., 17, 139-191, https://doi.org/10.1016/j.aeolia.2015.01.011, 2015.

Marzocchi, A. and Jansen, M. F.: Connecting Antarctic sea ice to deep-ocean circulation in modern and glacial climate simulations, Geophys. Res. Lett., 44, 6286-6295, https://doi.org/10.1002/2017GL073936, 2017.

Mendes, V. R., Sawakuchi, A. O., Chiessi, C. M., Giannini, P. C. F., Rehfeld, K., and Mulitza, S.: Thermoluminescence and Optically Stimulated Luminescence Measured in Marine Sediments Indicate Precipitation Changes Over Northeastern Brazil, Paleoceanography and Paleoclimatology, 34, 1476-1486, https://doi.org/10.1029/2019PA003691, 2019.

Menviel, L., Yu, J., Joos, F., Mouchet, A., Meissner, K. J., and England, M. H.: Poorly ventilated deep ocean at the Last Glacial Maximum inferred from carbon isotopes: A data-model comparison study, Paleoceanography, 32, 2-17, https://doi.org/10.1002/2016pa003024, 2017.

Morée, A. and Schwinger, J.: Last Glacial Maximum minus pre-industrial anomaly fields for use in forced ocean modelling, based on PMIP3, Norstore, https://doi.org/10.11582/2019.00011, 2019.

Morée, A. and Schwinger, J.: PMIP3-based Last Glacial Maximum (LGM) pre-industrial (PI) anomaly fields for addition to PI ocean model forcing, version 3, Norstore, https://doi.org/10.11582/2020.00052, 2020.

Muglia, J. and Schmittner, A.: Glacial Atlantic overturning increased by wind stress in climate models, Geophys. Res. Lett., 42, 9862-9868, https://doi.org/10.1002/2015gl064583, 2015.

NASA-GISS: GISS-E2-R model output prepared for CMIP5 pre-industrial control, served by ESGF WDCC at DKRZ, https://doi.org/10.1594/WDCC/CMIP5.GIGRpc, 2014a.

NASA-GISS: GISS-E2-R model output prepared for CMIP5 last glacial maximum, served by ESGF WDCC at DKRZ, https://doi.org/10.1594/WDCC/CMIP5.GIGRlg, 2014b.

Otto-Bliesner, B. L., Hewitt, C. D., Marchitto, T. M., Brady, E., Abe-Ouchi, A., Crucifix, M., Murakami, S., and Weber, S. L.: Last Glacial Maximum ocean thermohaline circulation: PMIP2 model intercomparisons and data constraints, Geophys. Res. Lett., 34, L12706, https://doi.org/10.1029/2007GL029475, 2007. 
Rahmstorf, S.: On the freshwater forcing and transport of the Atlantic thermohaline circulation, Clim. Dynam., 12, 799-811, https://doi.org/10.1007/s003820050144, 1996.

Rohling, E. J.: Paleosalinity: confidence limits and future applications, Mar. Geol., 163, 1-11, https://doi.org/10.1016/S00253227(99)00097-3, 2000

Schmidt, G. A., Kelley, M., Nazarenko, L., Ruedy, R., Russell, G. L., Aleinov, I., Bauer, M., Bauer, S. E., Bhat, M. K., Bleck, R., Canuto, V., Chen, Y.-H., Cheng, Y., Clune, T. L., Del Genio, A., de Fainchtein, R., Faluvegi, G., Hansen, J. E., Healy, R. J., Kiang, N. Y., Koch, D., Lacis, A. A., LeGrande, A. N., Lerner, J., Lo, K. K., Matthews, E. E., Menon, S., Miller, R. L., Oinas, V., Oloso, A. O., Perlwitz, J. P., Puma, M. J., Putman, W. M., Rind, D., Romanou, A., Sato, M., Shindell, D. T., Sun, S., Syed, R. A., Tausnev, N., Tsigaridis, K., Unger, N., Voulgarakis, A., Yao, M.-S., and Zhang, J.: Configuration and assessment of the GISS ModelE2 contributions to the CMIP5 archive, J. Adv. Model. Earth Sy., 6, 141-184, https://doi.org/10.1002/2013MS000265, 2014.

Schulzweida, U.: CDO User Guide (Version 1.9.6), Max Planck Institute for Meteorology, Bundesstraße 53, 20146 Hamburg, Germany, Zenodo, 215 pp., https://doi.org/10.5281/zenodo.2558193, 2019.

Schwinger, J., Goris, N., Tjiputra, J. F., Kriest, I., Bentsen, M., Bethke, I., Ilicak, M., Assmann, K. M., and Heinze, C.: Evaluation of NorESM-OC (versions 1 and 1.2), the ocean carboncycle stand-alone configuration of the Norwegian Earth System Model (NorESM1), Geosci. Model Dev., 9, 2589-2622, https://doi.org/10.5194/gmd-9-2589-2016, 2016.

Sénési, S., Richon, J., Franchistéguy, L., Tyteca, S., Moine, M.-P., Voldoire, A., Sanchez-Gomez, E., Salas y Mélia, D., Decharme, B., Cassou, C., Valcke, S., Beau, I., Alias, A., Chevallier, M., Déqué, M., Deshayes, J., Douville, H., Madec, G., Maisonnave, E., Planton, S., Saint-Martin, D., Szopa, S., Alkama, R., Belamari, S., Braun, A., Coquart, L., and Chauvin, F.: CNRM-CM5 model output prepared for CMIP5 piControl, served by ESGF, WDCC at DKRZ, https://doi.org/10.1594/WDCC/CMIP5.CEC5pc, 2014a.

Sénési, S., Richon, J., Franchistéguy, L., Tyteca, S., Moine, M.-P., Voldoire, A., Sanchez-Gomez, E., Salas y Mélia, D., Decharme, B., Cassou, C., Valcke, S., Beau, I., Alias, A., Chevallier, M., Déqué, M., Deshayes, J., Douville, H., Madec, G., Maisonnave, E., Planton, S., Saint-Martin, D., Szopa, S., Alkama, R., Belamari, S., Braun, A., Coquart, L., and Chauvin, F.: CNRM-CM5 model output prepared for CMIP5 lgm, served by ESGF, WDCC at DKRZ, https://doi.org/10.1594/WDCC/CMIP5.CEC5lg, 2014b.

Sime, L. C., Hodgson, D., Bracegirdle, T. J., Allen, C., Perren, B., Roberts, S., and de Boer, A. M.: Sea ice led to poleward-shifted winds at the Last Glacial Maximum: the influence of state dependency on CMIP5 and PMIP3 models, Clim. Past, 12, 2241-2253, https://doi.org/10.5194/cp-12-2241-2016, 2016.
Spence, J. P., Eby, M., and Weaver, A. J.: The Sensitivity of the Atlantic Meridional Overturning Circulation to Freshwater Forcing at Eddy-Permitting Resolutions, J. Climate, 21, 2697-2710, https://doi.org/10.1175/2007JCLI2103.1, 2008.

Sueyoshi, T., Ohgaito, R., Yamamoto, A., Chikamoto, M. O., Hajima, T., Okajima, H., Yoshimori, M., Abe, M., O'ishi, R., Saito, F., Watanabe, S., Kawamiya, M., and Abe-Ouchi, A.: Set-up of the PMIP3 paleoclimate experiments conducted using an Earth system model, MIROC-ESM, Geosci. Model Dev., 6, 819-836, https://doi.org/10.5194/gmd-6-819-2013, 2013.

Taylor, K. E., Stouffer, R. J., and Meehl, G. A.: An Overview of CMIP5 and the Experiment Design, B. Ame. Meteorol. Soc., 93, 485-98, https://doi.org/10.1175/BAMS-D-11-00094.1, 2011.

Voldoire, A., Sanchez-Gomez, E., Salas y Mélia, D., Decharme, B., Cassou, C., Sénési, S., Valcke, S., Beau, I., Alias, A., Chevallier, M., Déqué, M., Deshayes, J., Douville, H., Fernandez, E., Madec, G., Maisonnave, E., Moine, M. P., Planton, S., Saint-Martin, D., Szopa, S., Tyteca, S., Alkama, R., Belamari, S., Braun, A., Coquart, L., and Chauvin, F.: The CNRMCM5.1 global climate model: description and basic evaluation, Clim. Dynam., 40, 2091-2121, https://doi.org/10.1007/s00382011-1259-y, 2013.

Winguth, A. M. E., Archer, D., Duplessy, J. C., MaierReimer, E., and Mikolajewicz, U.: Sensitivity of paleonutrient tracer distributions and deep-sea circulation to glacial boundary conditions, Paleoceanography, 14, 304-323, https://doi.org/10.1029/1999PA900002, 1999.

Yukimoto, S., Adachi, Y., Hosaka, M., Sakami, T., Yoshimura, H., Hirabara, M., Tanaka, T. Y., Shindo, E., Tsujino, H., Deushi, M., Mizuta, R., Yabu, S., Obata, A., Nakano, H., Koshiro, T., Ose, T., and Kitoh, A.: A New Global Climate Model of the Meteorological Research Institute: MRI-CGCM3;Model Description and Basic Performance, J. Meteorol. Soc. Jpn. Ser. II, 90A, 23-64, https://doi.org/10.2151/jmsj.2012-A02, 2012.

Yukimoto, S., Adachi, Y., Hosaka, M., Sakami, T., Yoshimura, H., Hirabara, M., Tanaka, T., Shindo, E., Tsujino, H., Deushi, M., Mizuta, R., Yabu, S., Obata, A., Nakano, H., Koshiro, T., Ose, T., and Kitoh, A.: MRI-CGCM3 model output prepared for CMIP5 piControl, served by ESGF, WDCC at DKRZ, https://doi.org/10.1594/WDCC/CMIP5.MRMCpc, 2015a.

Yukimoto, S., Adachi, Y., Hosaka, M., Sakami, T., Yoshimura, H., Hirabara, M., Tanaka, T., Shindo, E., Tsujino, H., Deushi, M., Mizuta, R., Yabu, S., Obata, A., Nakano, H., Koshiro, T., Ose, T., and Kitoh, A.: MRI-CGCM3 model output prepared for CMIP5 lgm, served by ESGF, WDCC at DKRZ, https://doi.org/10.1594/WDCC/CMIP5.MRMClg, 2015b. 